\title{
Physiological Responses to Different Substrate Water Contents: Screening for High Water-use Efficiency in Bedding Plants
}

\author{
Krishna S. Nemali \\ Department of Land, Air, and Water Resources, University of California, One Shields Avenue, \\ Davis, CA 95616
}

\author{
Marc W. van Iersel ${ }^{1}$ \\ Horticulture Department, University of Georgia, 111 Plant Science Building, Athens, \\ GA 30602-7273
}

\begin{abstract}
AdDitional INDEX wORDs. A- $\mathrm{C}_{\mathrm{i}}$ responses, Catharanthus roseus, chlorophyll fluorescence, Impatiens wallerana, mesophyll conductance, Petunia $\times$ hybrida, photosynthesis, quantum efficiency, Salvia splendens

Abstract. Efficient use of irrigation water is increasingly important in the production of bedding plants. Two approaches to efficient water use include reducing irrigation water wastage during production by growing plants at the optimal substrate water content $(\theta)$ and growing species with high water-use efficiency (WUE). However, there is little information on the effects of different $\theta$ levels on leaf physiology of bedding plants and variation in WUE among different species of bedding plants. The objectives of this study were to determine the effects of $\theta$ on leaf water relations, gas exchange, chlorophyll fluorescence, and WUE of bedding plants and to identify the physiological basis for differences in WUE between two bedding plant species. We grew salvia 'Bonfire Red' (Salvia splendens Sellow ex Roemer \& J.A. Schultes), vinca 'Cooler Peppermint' [Catharanthus roseus (L.) G. Don.], petunia 'Lavender White' (Petunia $\times$ hybrida Hort ex. Vilm.), and impatiens 'Cherry' (Impatiens walleriana Hook F.) at four constant levels of $\theta\left(0.09,0.15,0.22\right.$, and $\left.0.32 \mathrm{~m}^{3} \cdot \mathrm{m}^{-3}\right)$ using an automated irrigation controller. Regardless of species, leaf water potential $\left(\Psi_{\mathrm{w}}\right)$ and leaf photosynthesis (A) of all four species were lower at a $\theta$ of $0.09 \mathrm{~m}^{3} \cdot \mathrm{m}^{-3}$ and were not different among the other $\theta$ levels, but stomatal conductance to $\mathrm{H}_{2} \mathrm{O}\left(g_{S}\right)$ was lower at 0.09 than at 0.15 and $0.22 \mathrm{~m}^{3} \cdot \mathrm{m}^{-3}$ and highest at $0.32 \mathrm{~m}^{3} \cdot \mathrm{m}^{-3}$. WUE of bedding plants at different $\theta$ levels depended on species. The WUE of petunia was unaffected by $\theta$, whereas for the other three species, WUE was higher at a $\theta$ of $0.09 \mathrm{~m}^{3} \cdot \mathrm{m}^{-3}$ than at $0.32 \mathrm{~m}^{3} \cdot \mathrm{m}^{-3}$. Differences in WUE between petunia and salvia were partly from differences in photosynthetic capacity between the two species. Based on the response of A to leaf internal $\mathrm{CO}_{2}$ concentration $\left(\mathrm{C}_{\mathrm{i}}\right)$, mesophyll conductance to $\mathrm{CO}_{2}\left[\mathrm{~g}_{\mathrm{m}}(\mathrm{a}\right.$ measure of photosynthetic capacity)] was higher in petunia than salvia, whereas gas phase conductance to $\mathrm{CO}_{2}\left(\mathrm{~g}_{\mathrm{CO}}\right)$ was similar for these two species, which resulted in higher WUE in petunia than salvia.
\end{abstract}

Decreasing water resources and a steadily increasing population in urban areas in the United States have increased pressure on the availability and usage of greenhouse irrigation water and have forced stricter government regulations of agricultural water use (Lea-Cox and Ross, 2001). To comply with new regulations, it has become important to optimize water use in greenhouse production in the United States. Bedding plants are among the most important greenhouse crops in the United States (U.S. Department of Agriculture, 2006); however, little work has been done to optimize water use in their production. Two factors combine to determine water use in bedding plant production; i.e., irrigation management practices that determine irrigation efficiency [IE (the ratio of the amount of water retained in the substrate to the volume supplied in irrigation)] and the water use efficiency (WUE) of bedding plants (the efficiency which with plants use water to produce dry matter).

IE is reduced by leaching and using irrigation systems that do not apply all of the water to the substrate in the containers or flats. For example, pot spacing may affect IE under overhead

Received for publication 7 June 2007. Accepted for publication 8 Jan. 2008. We thank Robert Teskey, Mark Rieger, David Radcliffe, and Paul Thomas for their comments on earlier drafts of the manuscript.

'Corresponding author. E-mail: mvanier@uga.edu and nemalikrishna@yahoo. com. irrigation, as much of the water may be applied to the space between pots when spacing is large, resulting in a low IE. Applying excess water will also reduce IE because of the resulting leaching. A high IE can be achieved by using automated irrigation controllers that apply water based on the substrate water content. Nemali and van Iersel (2006) developed an irrigation controller that maintains substrate water content at a user-defined set point. This controller applies water as water is lost from the substrate through evaporation or transpiration and results in little or no leaching. That makes it possible to achieve an IE close to $100 \%$. If needed, the controller can be adjusted to result in leaching, for example, to manage excess fertilizer salts in the substrate.

To use irrigation water more efficiently, it is critical to have a thorough understanding of the amount of water needed to produce bedding plants. Knowledge of the actual water requirements of bedding plant species is limited. A recent report has suggested that plants can grow normally at a $\theta$ level as low as $0.13 \mathrm{~m}^{3} \cdot \mathrm{m}^{-3}$ ( $\theta$ measured in the top $6-\mathrm{cm}$ of the substrate; Starman and Lombardini, 2006), whereas another report indicated a decrease in leaf photosynthesis with a decrease in the $\theta$ level from $\approx 0.30$ to $0.10 \mathrm{~m}^{3} \cdot \mathrm{m}^{-3}$ ( $\theta$ represents the average of whole pot; Niu et al., 2006). Clearly, more detailed investigations are required to determine the optimal range of $\theta$ for bedding plants. 
Crop WUE is a physiological parameter describing the relationship between plant water use and dry matter production. Increases in crop WUE would result in greater biomass produced per liter of water transpired and thus decrease the amount of water needed to produce the plants. Although WUE is commonly calculated as the ratio of A to transpiration $(\mathrm{E})$ in plants, $\mathrm{A} / g_{\mathrm{S}}$ is preferred, as $g_{\mathrm{S}}$ is less affected by environmental fluctuations than $\mathrm{E}$ and more closely reflects genetic differences among plants (Jones, 1992). A high WUE can occur when A is high or $g_{\mathrm{S}}$ is low. Though both conditions may result in the same outcome (high WUE), they can result in different responses at the whole-plant scale. As $g_{\mathrm{S}}$ regulates $\mathrm{CO}_{2}$ uptake and $\mathrm{H}_{2} \mathrm{O}$ loss from plants, a low $g_{\mathrm{S}}$ may increase WUE but decrease $\mathrm{CO}_{2}$ uptake and growth (Jones, 1992; Sheshshayee et al., 2005; Udayakumar et al., 1998). In bedding plant production, high growth rates are desired to minimize the production period, and plants often do not experience drought stress during production. Therefore, to attain a high WUE of bedding plants with a minimal impact on growth, the goal should be to achieve a high A or photosynthetic capacity per unit $g_{\mathrm{S}}$.

Mesophyll conductance to $\mathrm{CO}_{2}$ in plants is an indicator of photosynthetic capacity (Earl, 2002; Jones, 1985, 1998; Long and Bernacchi, 2003) and includes all effects on $\mathrm{CO}_{2}$ transfer conductance starting in the mesophyll cell wall, and ending with the carboxylation of ribulose-bisphosphate $(\mathrm{RuBP})$ by Rubisco. Mesophyll conductance can be estimated from the relationship of $A$ to $C_{i}$ in plants. The slope of this relationship at the leaf internal $\mathrm{CO}_{2}$ concentration where plants normally operate is a direct estimate of $\mathrm{g}_{\mathrm{m}}$ (Earl, 2002; Jones, 1985, 1998; Long and Bernacchi, 2003). Leaf photosynthesis is affected by $g_{m}$ and $g_{S}$, but $g_{m}$ commonly limits A more than $g_{\mathrm{S}}$ (Earl, 2002; Grassi and Magnani, 2005). Supporting this, a linear relation between $\mathrm{A}$ and $\mathrm{g}_{\mathrm{m}}$ has been found in several studies (De Lucia et al., 2003; Epron et al., 1995; Evans and Loreto, 2000; Loreto et al., 1992; Singsaas et al., 2003), whereas the relation between $\mathrm{A}$ and $g_{\mathrm{S}}$ often is curvilinear, with little increase in A at high levels of $g_{S}$ (Plaut et al., 2004). As E depends on $g_{S}$ but not $g_{m}$, an increase in $g_{S}$ without a proportional increase in A will reduce the WUE. Conversely, a high $\mathrm{g}_{\mathrm{m}}$ can increase photosynthetic capacity without an increase in E, thereby increasing WUE. However, there has been no research looking at $g_{m}$ and its possible effects on WUE of bedding plants.

Quantum efficiency during the light period reflects the capacity of photosystem II to use the absorbed light (Maxwell and Johnson, 2000). Quantum efficiency in light is linearly related to the photosynthetic performance of plants (Maxwell and Johnson, 2000). For example, shade-loving species have a low $\Phi_{\text {PSII }}$ because of their inherent low photosynthetic capacity (Adams and Demmig-Adams, 1992; Close et al., 2001; Evans and Poorter, 2001; Marenco et al., 2001). Quantum efficiency in light can be easily estimated using a fluorometer and provides a rapid way to estimate the photosynthetic capacity of plants.

In this study, we grew four different species of bedding plants (vinca, salvia, petunia, and impatiens) at different, constant $\theta$ levels and measured instantaneous gas exchange, chlorophyll fluorescence, and $\mathrm{A}-\mathrm{C}_{\mathrm{i}}$ responses of plants. The objectives of the study were to determine the effects of $\theta$ on the leaf water relations, gas exchange, chlorophyll fluorescence, and WUE of bedding plants and to determine whether there are differences in WUE among species and whether such differences are related to photosynthetic capacity.

\section{Materials and Methods}

Plant material. Seeds of salvia 'Bonfire Red', vinca 'Cooler Peppermint', petunia 'Lavender White', and impatiens 'Cherry' were sown in 128-cell plug-flats and germinated under a mist system. About 4 weeks after germination, seedlings were transplanted into plastic containers $(30.4 \times 45.7 \times 17.0 \mathrm{~cm} ; 17.5$ L) filled with a soilless substrate (Fafard 2P mix containing $60 \%$ peat and $40 \%$ perlite; Fafard, Anderson, SC) to which a slow-release fertilizer [Osmocote 14-14-14 (14.0N-6.2P$11.6 \mathrm{~K})$; Scotts Co., Marysville, $\mathrm{OH}]$ was added $(22.5 \mathrm{~g} /$ container). One plant from each of the four species was transplanted into each container (in total, four plants/container) to assure that plants from all species were exposed to similar levels of $\theta$ in the different treatments (see below). Temperature, relative humidity (HTO-45R; Rotronic Instruments, Crawley, $\mathrm{UK}$ ), and photosynthetic photon flux (PPF; QSO-Sun; Apogee Instruments, Logan, UT) were measured by interfacing the sensors with a data logger (CR10X, Campbell Scientific, Logan, UT). Mean daily minimum and maximum relative humidity were $51.5 \%$ and $82.4 \%$, respectively, with an average of $67.0 \%$, while mean daily minimum and maximum temperature were $18.5^{\circ} \mathrm{C}$ and $25.6^{\circ} \mathrm{C}$, respectively, with an average of $22.1^{\circ} \mathrm{C}$. The daily light integral was $10.73 \pm 6.57 \mathrm{~mol} \cdot \mathrm{m}^{-2} \cdot \mathrm{d}^{-1}$ during the experiment.

WATERING System. Plants were watered with a drip irrigation system controlled by an automated irrigation controller (Nemali and van Iersel, 2006) that was programmed to maintain different set points of $\theta$ in the various treatments. The irrigation controller monitored $\theta$ in each container once every $20 \mathrm{~min}$ using temperature-corrected $\mathrm{ECH}_{2} \mathrm{O}-10$ dielectric moisture sensors (Decagon Devices, Pullman, WA). The moisture sensors (one per container) were inserted into the substrate at an angle at the center of the container and covered the entire depth. When the $\theta$ dropped below the set point for a particular container, the controller opened a solenoid valve specific to that container, which resulted in irrigation. The controller was programmed to open the solenoid valve for $1 \mathrm{~min}$ during which $\approx 100 \mathrm{~mL}$ of water was added to the substrate. This increased $\theta$ by $\approx 0.02$ to $0.03 \mathrm{~m}^{3} \cdot \mathrm{m}^{-3}$ after each irrigation. To allow $\theta$ to equilibrate in the substrate, a minimum of 19 min was allowed between irrigations. We maintained a high $\theta(0.32 \pm 0.02$ $\mathrm{m}^{3} \cdot \mathrm{m}^{-3}$ ) in all treatments for a period of 2 weeks after transplanting to allow seedling establishment. The set points in the controller were then changed to the respective treatment levels. Slight leaching from pots was noticed at a $\theta$ level of 0.32 $\mathrm{m}^{3} \cdot \mathrm{m}^{-3}$ after each irrigation; however, the volume of leachate was not quantified.

Treatments and measurements. Sixteen treatments consisting of four species each grown at four irrigation set points $\left(0.09,0.15,0.22\right.$, and $\left.0.32 \mathrm{~m}^{3} \cdot \mathrm{m}^{-3}\right)$ were included in the study. When the $\theta$ in different treatments was steady (days 20-40, Fig. 1 ), weekly measurements were made on fully expanded leaves at the top of the canopy. Parameters measured included A, $\mathrm{g}_{\mathrm{S}}$, $\mathrm{C}_{\mathrm{i}}, \Psi_{\mathrm{w}}$, and $\Phi_{\mathrm{PSII}}$ of plants. Gas exchange measurements $\left(\mathrm{CO}_{2}\right.$ and $\mathrm{H}_{2} \mathrm{O}$ ) were made three times during the study at a $P P F$ of $1000 \mu \mathrm{mol} \cdot \mathrm{m}^{-2} \cdot \mathrm{s}^{-1}$, a temperature of $25^{\circ} \mathrm{C}$, a relative humidity of $70 \%$, and a $\mathrm{CO}_{2}$ concentration $\left(\mathrm{C}_{\mathrm{a}}\right)$ of $400 \mu \mathrm{mol} \cdot \mathrm{mol}^{-1}$ using a leaf photosynthesis system (CIRAS-1; PP Systems, Amesbury, MA) equipped with an LED light unit. Midday leaf water potential was measured twice during the study using leafcutter thermocouple psychrometers (Model 76; J.R.D. Merrill 


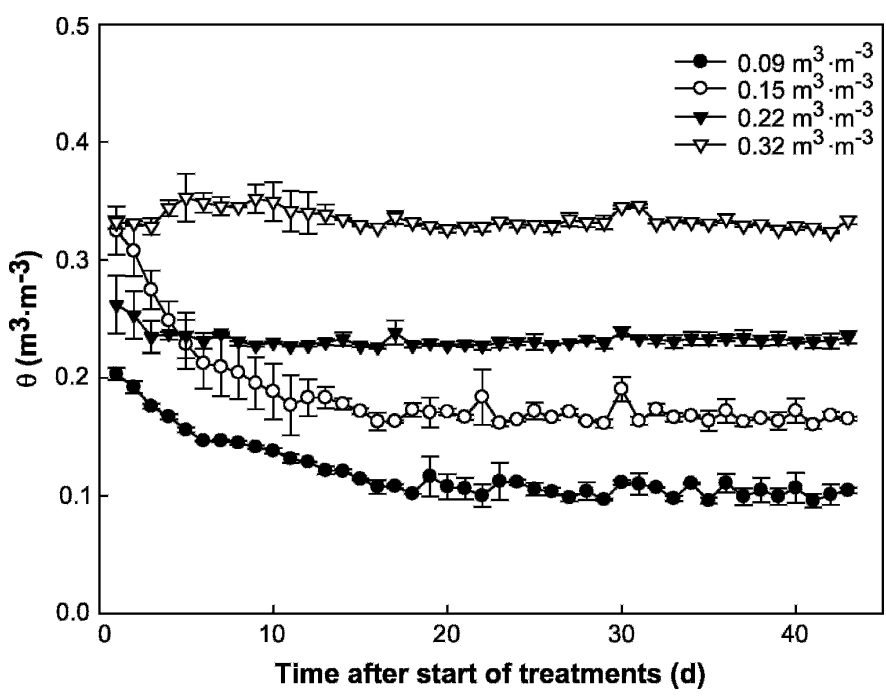

Fig. 1. Daily average substrate volumetric water content $(\theta, n=2)$ maintained by the custom-made automated watering system at different irrigation set points throughout the study. An automated watering system was used to maintain different irrigation set points for petunia, salvia, impatiens, and vinca to study the physiological responses to varying substrate water content. The automated watering system uses temperature-compensated, calibrated $\mathrm{ECH}_{2} \mathrm{O}-10$ (Decagon Devices) moisture sensors and solenoids interfaced to a CR10X datalogger (Campbell Scientific) for irrigation monitoring and control. Different symbols in the graph indicate daily mean water content maintained at different set points programmed into the irrigation controller. Error bars represent standard deviation of the mean.

Specialty Equipment, Logan, UT) after equilibration in a water bath at $25^{\circ} \mathrm{C}$ for $4 \mathrm{~h}$. A chlorophyll fluorometer (Mini-PAM; Heinz Walz GmbH, Effeltrich, Germany) was used to estimate $\Phi_{\text {PSII }}$ (measured three times during the study) after exposing leaves to a $P P F$ of 1000 to $1100 \mu \mathrm{mol} \cdot \mathrm{m}^{-2} \cdot \mathrm{s}^{-1}$ for a period of $3 \mathrm{~min}$. At the end of the study, A- $\mathrm{C}_{\mathrm{i}}$ responses were measured for petunia and salvia grown at $\theta$ levels of 0.15 and $0.22 \mathrm{~m}^{3} \cdot \mathrm{m}^{-3}$ under similar cuvette conditions as described earlier. The ambient $\mathrm{CO}_{2}$ concentration in the cuvette was decreased from 400 to $25 \mu \mathrm{mol} \cdot \mathrm{mol}^{-1}$ and was subsequently increased to 700 $\mu \mathrm{mol} \cdot \mathrm{mol}^{-1}$ at steps of $\approx 100 \mu \mathrm{mol} \cdot \mathrm{mol}^{-1}$ to prevent feedback inhibition during measurement. The rate of photosynthesis at each $\mathrm{C}_{\mathrm{a}}$ was measured after attaining steady state.

Calculations, experimental Design, and STATistical ANALYSES. For the $\mathrm{A}-\mathrm{C}_{\mathrm{i}}$ analysis, a nonlinear regression $\{\mathrm{A}=$ $\mathrm{A}_{0}+\left[\left(\mathrm{a} \times \mathrm{C}_{\mathrm{i}}\right) /\left(\mathrm{b}+\mathrm{C}_{\mathrm{i}}\right)\right]$, where $\mathrm{A}_{0}$ is the estimated photosynthetic rate when $C_{i}$ is $0, A_{0}+a$ is the maximum attainable $A$ at saturating $C_{i}$, and $b$ is a regression coefficient $\}$ was fitted using SAS (SAS Institute, Cary, NC).

The $\mathrm{CO}_{2}$ compensation point $(\Gamma)$ was calculated from the fitted rectangular hyperbolic equation as the $C_{i}$ when the photosynthetic rate was zero:

$$
\Gamma=-\left(A_{0} \times b\right) /\left(A_{0} \times a\right) .
$$

Rubisco efficiency $(\varphi)$ was calculated as the slope of the $A-C_{i}$ response curve at $\Gamma$ :

$$
\varphi=(\mathrm{a} \times \mathrm{b}) /(\mathrm{b} \times \Gamma)^{2}
$$

Gas phase conductance to $\mathrm{CO}_{2}\left(\mathrm{~g}_{\mathrm{CO}_{2}}\right.$, the sum of the boundary layer and $g_{\mathrm{S}}$ ) was calculated as (Jones, 1985):

$$
\mathrm{gco}_{2}=-\left(\mathrm{C}_{\mathrm{a}}-\mathrm{C}_{\mathrm{i}}\right) / \mathrm{A}_{\mathrm{OP}} \text {, }
$$

where $\mathrm{A}_{\mathrm{OP}}$ is the assimilation rate at the operating point (the $\mathrm{C}_{\mathrm{i}}$ at an ambient $\mathrm{CO}_{2}$ concentration of $400 \mu \mathrm{mol} \cdot \mathrm{mol}^{-1}$ ).
Mesophyll conductance to $\mathrm{CO}_{2}\left(\mathrm{~g}_{\mathrm{m}}\right)$ was calculated as slope of $\mathrm{A}-\mathrm{C}_{\mathrm{i}}$ curves at the operating point as (Jones, 1985):

$$
\mathrm{g}_{\mathrm{m}}=\mathrm{a} \times \mathrm{b} /\left(\mathrm{b}+\mathrm{C}_{\mathrm{i}}\right)^{2}
$$

WUE was calculated using two methods, i.e., as $\mathrm{A} / g_{\mathrm{S}}$ from instantaneous leaf gas exchange measurements and as $\mathrm{A}_{\mathrm{OP}} / \mathrm{g}_{\mathrm{CO}_{2}}$ using estimates from the $\mathrm{A}-\mathrm{C}_{\mathrm{i}}$ analyses.

The experimental design was a split-plot design with two replications. A container with all four species was a main plot, with the species as the split. The main plot represented a treatment level (irrigation set point). There were two containers per treatment within each replication (16 containers in total). A measurement unit consisted of one plant belonging to a species in a container at each treatment level. To increase the precision of estimates that could be affected by limited number of replications (2) used in the study, treatment means were based on two sample plants per replication, each measured multiple (2-3) times. Moreover, the $\theta$ varied little between replicates within a treatment level, reducing the experimental error. Nonetheless, the use of only two replications may have affected our ability to statistically detect treatment effects. Data were analyzed using analysis of variance (ANOVA) and regression procedures $(P<0.05$ was considered significant) from SAS. The $A-C_{i}$ curves were fit using nonlinear regression, and the physiological parameters estimated from these curves were subsequently analyzed using ANOVA. Mean separation followed ANOVA using Fisher's protected least significant difference (for effects with significant interactions) and Tukey's honestly significant difference procedure (for main effects where interactions were not significant).

\section{Results and Discussion}

\section{Substrate water content effects on leaf physiology}

SubSTRATE WATER CONTENT AT DIFFERENT IRRIGATION SET POINTS. The irrigation controller started maintaining $\theta$ soon after the start of the experiment in the two wetter treatments $\left(0.22\right.$ and $\left.0.32 \mathrm{~m}^{3} \cdot \mathrm{m}^{-3}\right)$, whereas it took 15 to $18 \mathrm{~d}$ for the substrate to dry-down to the set points in the two drier treatments $\left(0.09\right.$ and $0.15 \mathrm{~m}^{3} \cdot \mathrm{m}^{-3}$; Fig. 1). The irrigation controller maintained $\theta$ in all treatments from days 20 to 43 . Variations in environmental conditions during the study (relative humidity and daily light integral) did not affect the efficacy of the irrigation controller, as the $\theta$ maintained was never $>3 \%$ higher than the set point in any of the treatments (Fig. 1). The mean $\theta( \pm \mathrm{SD})$ from days 20 through 40 were $0.104 \pm 0.001$ $\mathrm{m}^{3} \cdot \mathrm{m}^{-3}, 0.168 \pm 0.002 \mathrm{~m}^{3} \cdot \mathrm{m}^{-3}, 0.231 \pm 0.003 \mathrm{~m}^{3} \cdot \mathrm{m}^{-3}$, and $0.331 \pm$ $0.003 \mathrm{~m}^{3} \cdot \mathrm{m}^{-3}$ at set points of $0.09,0.15,0.22$, and $0.32 \mathrm{~m}^{3} \cdot \mathrm{m}^{-3}$, respectively.

Physiological responses of plants to $\theta$ are usually studied using the dry-down (plants exposed to different levels of $\theta$ after irrigation is stopped) or pot-weighing techniques (plants exposed to distinct $\theta$ levels or subjected to controlled dry-down as the substrate is replenished with a fraction of the volume of water lost between irrigations; Ekanayake et al., 1993; Ray and Sinclair, 1998; Sinclair and Ludlow, 1986). In the former method, observed responses can be confounded by the rate of change in $\theta$, which depends on the prevailing environment (Cornic et al., 1987; Earl, 2002; Ludlow, 1987; Saccardy et al., 1996), size of the plants, and volume of the substrate. The latter method is labor intensive and comparing species with different water use patterns could further complicate the interpretation of 
the data. To avoid these problems in this study, we grew species together in containers and maintained distinct $\theta$ levels (as opposed to uncontrolled or controlled dry-down regimes described above) using an automated watering system that uses calibrated moisture sensors (Fig. 1; also, see Nemali and van Iersel, 2006). Because plants of all four species were grown together in the same container, they were exposed to similar $\theta$ levels in any treatment. Moreover, the watering system maintained $\theta$ close to the set points (Fig. 1) throughout the experiment. Because of this, it is unlikely that our results were confounded by differences in $\theta$ among species within the same treatment.

Midday leaf WATER POTEntial. There was no interaction between species and irrigation set point with regard to midday $\Psi_{\mathrm{W}}$. Regardless of $\theta$, vinca had the lowest midday $\Psi_{\mathrm{W}}$, whereas impatiens had a higher midday $\Psi_{\mathrm{W}}$ than salvia (Fig. 2A). Regardless of species, midday $\Psi_{\mathrm{W}}$ was lowest at a $\theta$ of $0.09 \mathrm{~m}^{3} \cdot \mathrm{m}^{-3}$. Surprisingly, $\Psi_{\mathrm{W}}$ did not differ among the other three $\theta$ levels (Fig. 2B). Though a decrease in leaf water potential is associated with drought (Sato et al., 2004), it was reported in seedlings of tropical rainforest species that decreased $g_{\mathrm{S}}$ aided in maintaining midday $\Psi_{\mathrm{W}}$ during periods of water stress (Bonal and Guehl, 2001). Similar responses were seen in olive (Olea europea L.) where midday $\Psi_{\mathrm{W}}$ did not differ among plants irrigated with amounts varying from $50 \%$ to $100 \%$ of evapotranspiration (Wahbi et al., 2005).

Рнотosynthesis AND $\boldsymbol{g}_{\mathbf{s}}$. There was no interaction between species and irrigation set point with regard to A. Regardless of $\theta$, A of vinca was greater than that of salvia and impatiens and not different from that of petunia, whereas A of petunia was not different from that of salvia but higher than that of impatiens (Fig. 3A). The photosynthetic rate of all species was lowest at a $\theta$ of $0.09 \mathrm{~m}^{3} \cdot \mathrm{m}^{-3}$, whereas A did not differ among the other $\theta$ levels (Fig. 3B). Photosynthesis in vinca, salvia, petunia, and impatiens ranged from 10 to $15 \mu \mathrm{mol} \cdot \mathrm{m}^{-2} \cdot \mathrm{s}^{-1}$; Fig. $3 \mathrm{~A}$ ), which is lower than that of many vegetable crops $\left(20-25 \mu \mathrm{mol} \cdot \mathrm{m}^{-2} \cdot \mathrm{s}^{-1}\right.$; Kyei-boahen et al., 2003; Liu et al., 2006; Plaut et al., 2004), but within the range seen for several floricultural crops ( 8 to $18 \mu \mathrm{mol} \cdot \mathrm{m}^{-2} \cdot \mathrm{s}^{-1}$; Baille et al., 1996; Funnell et al., 2002; Leonardos et al.,1994; Niu et al., 2006). Among the four spe-
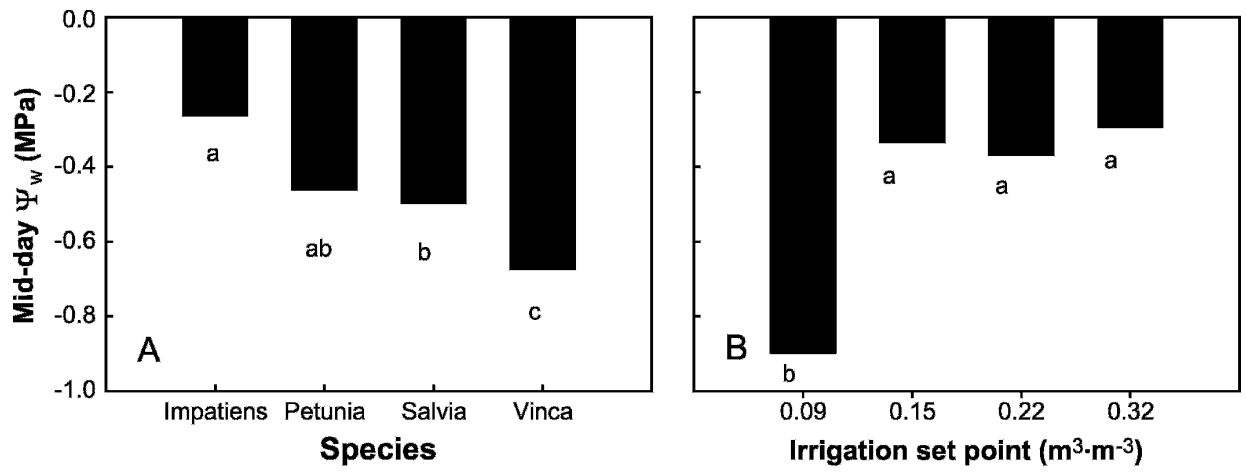

Fig. 2. Differences in leaf water status of plants grown under different irrigation set points maintained by an automated watering system. The watering system used temperature-compensated, calibrated $\mathrm{ECH}_{2} \mathrm{O}-10$ (Decagon Devices) moisture sensors and solenoids interfaced to a CR10X datalogger (Campbell Scientific) for irrigation monitoring and control to maintain a targeted substrate water content in different treatments. Actual substrate water content was maintained close to the irrigation set points throughout the experiment (see Fig. 1). Graphs indicate (A) time averaged (two times) mean (of four irrigation set points) midday leaf water potential $\left(\Psi_{\mathrm{W}}\right)$ in petunia, salvia, impatiens, and vinca $(\mathrm{n}=2$ for each irrigation set point) and (B) time averaged (two times) mean (of four species) midday $\Psi_{\mathrm{W}}$ at different irrigation set points $(\mathrm{n}=2$ for each species). Means were separated by Tukey's HSD $(P<0.05)$. cies, the lower A in impatiens (Fig. 3A) may be associated with its shade-loving nature because shade-loving species have an inherently low photosynthetic capacity (Adams and DemmigAdams, 1992; Nemali and van Iersel, 2004).

Leaf water status is known to affect A in plants (Lawlor, 2002; Parry et al., 2002; Tezara et al., 1999). The fact that midday $\Psi_{\mathrm{W}}$ was not significantly different among $\theta$ levels of $0.15,0.22$, and $0.32 \mathrm{~m}^{3} \cdot \mathrm{m}^{-3}$ could be one of the reasons for the lack of differences in A among these $\theta$ levels, while A and $\Psi_{\mathrm{W}}$ were lower at a $\theta$ of $0.09 \mathrm{~m}^{3} \cdot \mathrm{m}^{-3}$. However, the interplay of other factors such as differences in root development, xylem conductance, osmotic adjustment, and stomatal and nonstomatal conductance to $\mathrm{CO}_{2}$ among species also could have contributed to the lack of differences in A at $\theta$ levels of 0.15 , 0.22 , and $0.32 \mathrm{~m}^{3} \cdot \mathrm{m}^{-3}$. Our results are in line with reports available from diverse groups of plants that indicate a threshold of $\theta$ for A to decrease and above which no or small differences in A are usually seen (Gindaba et al., 2005; McCree, 1986; Olson et al., 2002; Xu and Zhou, 2005).

There was no species effect on $g_{\mathrm{S}}$. Regardless of species, $g_{\mathrm{S}}$ was highest at a $\theta$ of $0.32 \mathrm{~m}^{3} \cdot \mathrm{m}^{-3}$, did not differ between 0.15 a. $0.22 \mathrm{~m}^{3} \cdot \mathrm{m}^{-3}$, and lowest at $0.09 \mathrm{~m}^{3} \cdot \mathrm{m}^{-3}$ (Fig. 3C). There was an $\approx 3$-fold difference in $\mathrm{g}_{\mathrm{S}}$ between the 0.32 and $0.09 \mathrm{~m}^{3} \cdot \mathrm{m}^{-3}$ treatments, and there was only a 2-fold increase in A (Fig. 3, B and $\mathrm{C}$ ). The magnitude of $g_{\mathrm{S}}$ at different $\theta$ levels (Fig. $3 \mathrm{C}$ ), , was within the range seen in many vegetable crops (Kyei-boahen et al., 2003; Liu et al., 2006; Plaut et al., 2004). These results indicate that at 0.15 and $0.22 \mathrm{~m}^{3} \cdot \mathrm{m}^{-3}$, water loss from plants will be lower (as $g_{\mathrm{S}}$ was lower), whereas their leaf $\mathrm{CO}_{2}$ fixation rate will not be reduced compared with those at $0.32 \mathrm{~m}^{3} \cdot \mathrm{m}^{-3}$.

\section{Screening species for high WUE from high photosynthetic capacity}

WUE. There was an interactive effect of species and irrigation set point on WUE (estimated as $\mathrm{A} / g_{\mathrm{S}}$ averaged over three measurement times; Fig. 4). Except for petunia, WUE was lower in the wettest $\left(0.32 \mathrm{~m}^{3} \cdot \mathrm{m}^{-3}\right)$ than in the driest $(0.09$ $\mathrm{m}^{3} \cdot \mathrm{m}^{-3}$ ) treatment (Fig. 4). Low A and $\mathrm{g}$ were tradeoffs for higher WUE at $0.09 \mathrm{~m}^{3} \cdot \mathrm{m}^{-3}$ compared with $0.32 \mathrm{~m}^{3} \cdot \mathrm{m}^{-3}$ in impatiens, salvia, and vinca. In many studies, high WUE from low $g_{S}$ has been reported as a response to drought stress (Araus et al., 2002; McKay et al., 2003; Niu et al., 2006). There were no differences in WUE between the two intermediate $\theta$ treatments (0.15 and $0.22 \mathrm{~m}^{3} \cdot \mathrm{m}^{-3}$; Fig. 4). Only for impatiens was WUE lower at a $\theta$ level of 0.15 than at $0.09 \mathrm{~m}^{3} \cdot \mathrm{m}^{-3}$ (Fig. 4). In impatiens and petunia, WUE was not different between $\theta$ levels of 0.22 and $0.32 \mathrm{~m}^{3} \cdot \mathrm{m}^{-3}$, whereas it was lower at a $\theta$ level of 0.32 than $0.22 \mathrm{~m}^{3} \cdot \mathrm{m}^{-3}$ in vinca. The WUE of these four bedding plant species was in the same range as that of vegetable (Kyei-boahen et al., 2003; Liu et al., 2006; Plaut et al., 2004) and nut crops (Piel et al., 2002), as estimated from their reported measurements of $\mathrm{A}$ and $g_{\mathrm{S}}$. 

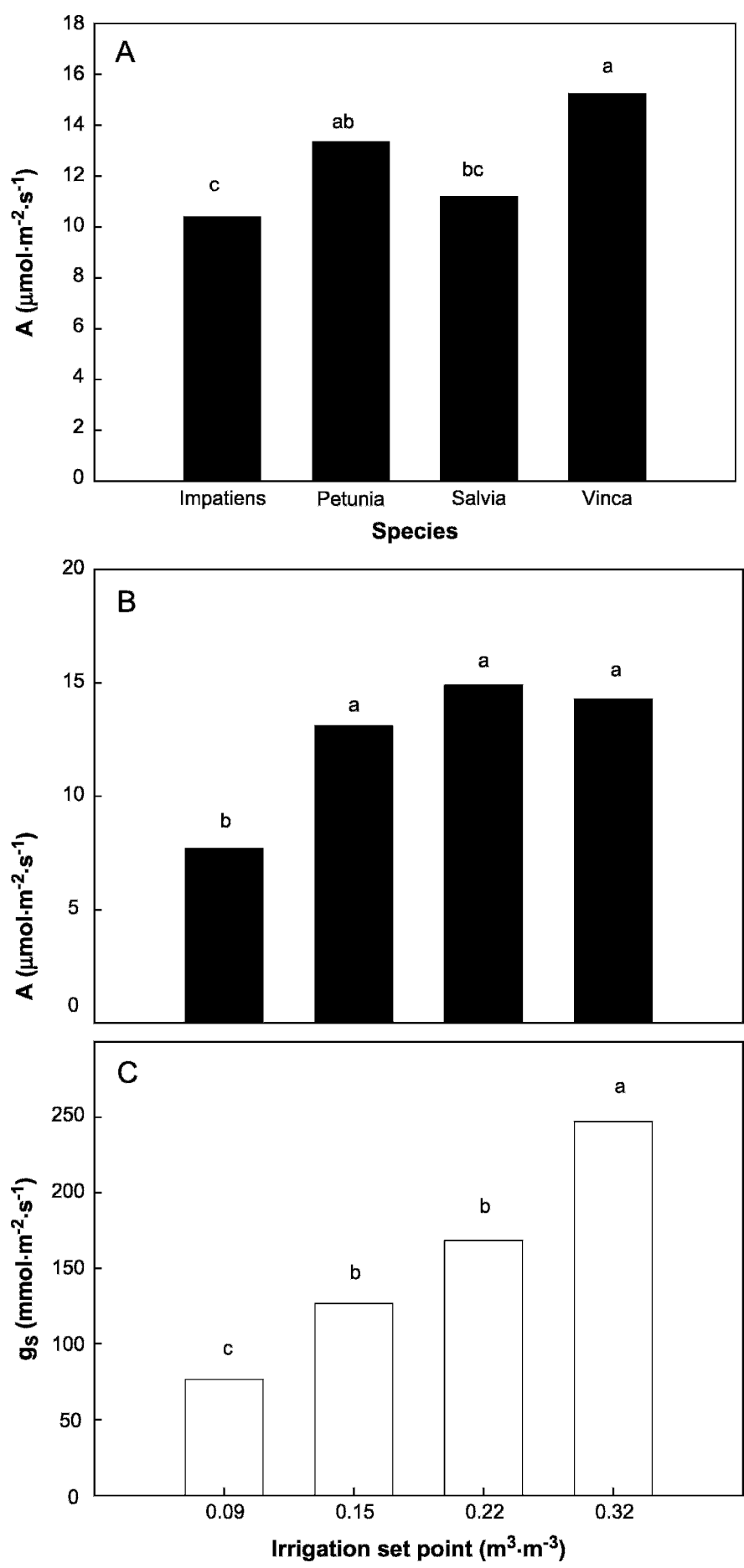

Fig. 3. Differences in gas exchange rate of plants grown under different irrigation set points maintained by an automated watering system. An automated watering system that uses temperature-compensated, calibrated $\mathrm{ECH}_{2} \mathrm{O}-10$ (Decagon Devices) moisture sensors and solenoids interfaced to a CR10X datalogger (Campbell Scientific) for irrigation monitoring and control was used to maintain a targeted substrate water content in different treatments. Graphs indicate (A) time averaged (three times) mean (of four irrigation set points) leaf photosynthetic rate (A) in petunia, salvia, impatiens, and vinca ( $\mathrm{n}$ $=2$ for each irrigation set point), (B) time averaged (three times) mean (of four species) leaf photosynthetic rate $(\mathrm{A})$, and $(\mathbf{C})$ time averaged (three times) mean (of four species) $g_{S}$ to water $\left(g_{S}\right)$ at different irrigation set points $(n=2$ for each species). Note that Figs. 3B and 3C, have the same labels for $\mathrm{X}$-axis. Means were separated by Tukey's HSD $(P<0.05)$.

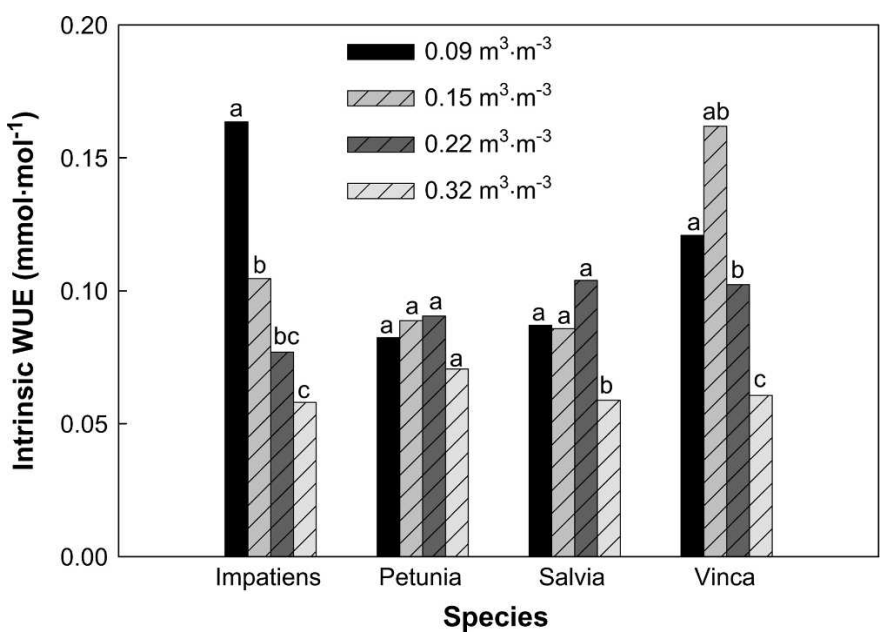

Fig. 4. Interactive effect of irrigation set point and species on WUE of bedding plants (petunia, salvia, impatiens, and vinca) grown under different irrigation regimes using an automated watering system that uses temperaturecompensated, calibrated $\mathrm{ECH}_{2} \mathrm{O}-10$ (Decagon Devices) moisture sensors and solenoids interfaced to a CR10X datalogger (Campbell Scientific) for irrigation monitoring and control. WUE was measured as the ratio of timeaveraged (three times) instantaneous photosynthetic rate to $g_{\mathrm{S}}$ to $\mathrm{H}_{2} \mathrm{O}$ in plants. Mean separation was shown within species. Means were separated using Fisher's protected LSD $(P<0.05)$. Means within a species not followed by the same letter are significantly different from each other.

QuANTUM EFFICIENCY IN LIGHT. Quantum efficiency depended on species and irrigation set point, but not on their interaction. There were no differences between vinca and petunia or between salvia and impatiens in $\Phi_{\mathrm{PSII}}$, but vinca and petunia had a higher $\Phi_{\text {PSII }}$ than salvia and impatiens (Fig. $5 \mathrm{~A})$. The quantum efficiency of impatiens was only half of that of vinca and $\approx 60 \%$ of that of petunia. Interspecific differences in $\Phi_{\text {PSII }}$ were larger than those resulting from manipulating $\theta$. Quantum efficiency was highest in the two wetter treatments $\left(0.32\right.$ and $\left.0.22 \mathrm{~m}^{3} \cdot \mathrm{m}^{-3}\right)$ and lowest in the two drier treatments $\left(0.09\right.$ and $0.15 \mathrm{~m}^{3} \cdot \mathrm{m}^{-3}$; Fig. 5B). A reduction in $\Phi_{\text {PSII }}$ from drought stress has also been reported in other studies (Colom and Vazzana, 2003; Epron, 1997; Flexas et al., 1999).

Photosynthesis-leaf internal $\mathrm{CO}_{2}$ Responses, and STOMATAL AND MESOPHYLL CONDUCTANCE TO $\mathrm{CO}_{2}$. There were interspecific differences in $\Phi_{\text {PSII }}$ between petunia (higher $\Phi_{\text {PSII }}$ ) and salvia (lower $\Phi_{\text {PSII }}$ ) and differences in $\Phi_{\text {PSII }}$ were also seen for all species between $\theta$ levels of 0.15 (lower $\Phi_{\text {PSII }}$ ) and 0.22 $\mathrm{m}^{3} \cdot \mathrm{m}^{-3}$ (higher $\Phi_{\mathrm{PSII}}$ ). Moreover, regardless of species and $\theta$ levels, there was a significant linear relationship between $\Phi_{\text {PSII }}$ and $\mathrm{A}\left(\mathrm{A}=3.4+34.8 \times \Phi_{\mathrm{PSII}}, r^{2}=0.60\right)$. Therefore, the differences in $\Phi_{\text {PSII }}$ suggested that there may be differences in photosynthetic capacity between petunia and salvia at $\theta$ levels of 0.15 and $0.22 \mathrm{~m}^{3} \cdot \mathrm{m}^{-3}$. Hence, $\mathrm{A}-\mathrm{C}_{\mathrm{i}}$ responses in petunia and salvia were studied at $\theta$ levels of 0.15 and $0.22 \mathrm{~m}^{3} \cdot \mathrm{m}^{-3}$ to estimate $g_{m}$. We expected that differences in $g_{m}$ would confirm the differences in photosynthetic capacity, which may in turn cause differences in WUE.

There was an interactive effect of species and $\theta$ on the shape of the $A-C_{i}$ curves. Rubisco efficiency (the slope of the $A-C_{i}$ response curve at $\Gamma)$ was lower at a $\theta$ level of $0.15 \mathrm{~m}^{3} \cdot \mathrm{m}^{-3}(66 \pm$ $22 \mathrm{mmol} \cdot \mathrm{m}^{-2} \cdot \mathrm{s}^{-1}$, mean $\left.\pm \mathrm{SD}\right)$ than at $0.22 \mathrm{~m}^{3} \cdot \mathrm{m}^{-3}(199 \pm 49$ $\left.\mathrm{mmol} \cdot \mathrm{m}^{-2} \cdot \mathrm{s}^{-1}\right)$, whereas in petunia, $\varphi$ was unaffected by $\theta$ $\left(0.164 \pm 0.012 \mathrm{~mol} \cdot \mathrm{m}^{-2} \cdot \mathrm{s}^{-1}\right)$. A drought-induced reduction in $\varphi$ 
was also reported in sunflower (Helianthus annuus L.; Tezara et al., 1999), similar to our results with salvia. There was no interactive effect of species and $\theta$ on any of the other relevant parameters determined from the A- $C_{i}$ curves, and data were averaged over the two $\theta$ levels to facilitate species comparisons (Table 1). The $\mathrm{CO}_{2}$ compensation points were not different between species, whereas $\mathrm{C}_{\mathrm{i}}$ at the operating point was lower and $\mathrm{A}$ at the operating point was higher in petunia compared with salvia (Table 1). Gas phase conductance to $\mathrm{CO}_{2}$ at the operating point did not differ between species, whereas $g_{m}$ was higher in petunia than in salvia (Table 1). Several studies have shown a decrease in $\mathrm{g}_{\mathrm{CO}_{2}}$ in response to $\theta$ (Earl, 2002; Grassi and Magnani, 2005), suggesting that our drought stress may not have been severe enough to cause significant changes in $\mathrm{g}_{\mathrm{CO}_{2}}$.

Based on previous results, responses of $g_{m}$ to $\theta$ may be species specific. Although there was no difference in $g_{m}$ between the control and drought treatments in two cultivars of soybean (Glycine max Merr.; Earl, 2002), there was a decrease in $g_{m}$ in response to drought stress in ash (Fraxinus Marshall) and oak (Quercus L.) trees (Grassi and Magnani, 2005). Our results indicate a difference in $g_{m}$ between the two species, but no effect of $\theta$.

Regardless of $\theta$, WUE at the operating point (estimated as $\mathrm{A}_{\mathrm{OP}} / \mathrm{g}_{\mathrm{CO}_{2}}$ ) was higher in petunia than salvia (Table 1) and was higher at a $\theta$ of $0.15 \mathrm{~m}^{3} \cdot \mathrm{m}^{-3}\left(0.24 \pm 0.02 \mathrm{mmol} \cdot \mathrm{mol}^{-1}\right)$ compared with $0.22 \mathrm{~m}^{3} \cdot \mathrm{m}^{-3}(0.21 \pm$ $0.02 \mathrm{mmol} \cdot \mathrm{mol}^{-1}$ ) in both species. When WUE was estimated as the ratio of instantaneous $\mathrm{A} / g_{\mathrm{S}}$ (Fig. 4), there were no differences between irrigation set points of 0.15 and $0.22 \mathrm{~m}^{3} \cdot \mathrm{m}^{-3}$ in salvia and petunia. WUE estimates from $\mathrm{A}-\mathrm{C}_{\mathrm{i}}$ analyses were based on regression equations fitted using several measurements of $\mathrm{A}$ at different levels of $\mathrm{C}_{\mathrm{i}}$, whereas instantaneous estimates of WUE were based on single measures of $\mathrm{A}$ and $g_{\mathrm{S}}$, potentially making those values less accurate. The higher $\mathrm{g}_{\mathrm{m}}$ in petunia compared with salvia (Table 1) and no differences in $\mathrm{g}_{\mathrm{CO}_{2}}$ reflect the influence of high photosynthetic capacity (high $\mathrm{g}_{\mathrm{m}}$ ) on WUE in petunia.

The operating point is midpoint between the RuBP-saturating and RuBP-limiting zones of A- $\mathrm{C}_{\mathrm{i}}$ curves (Lambers et al., 1998). Interspecific differences between salvia and petunia in our analysis of physiological responses at the operating point

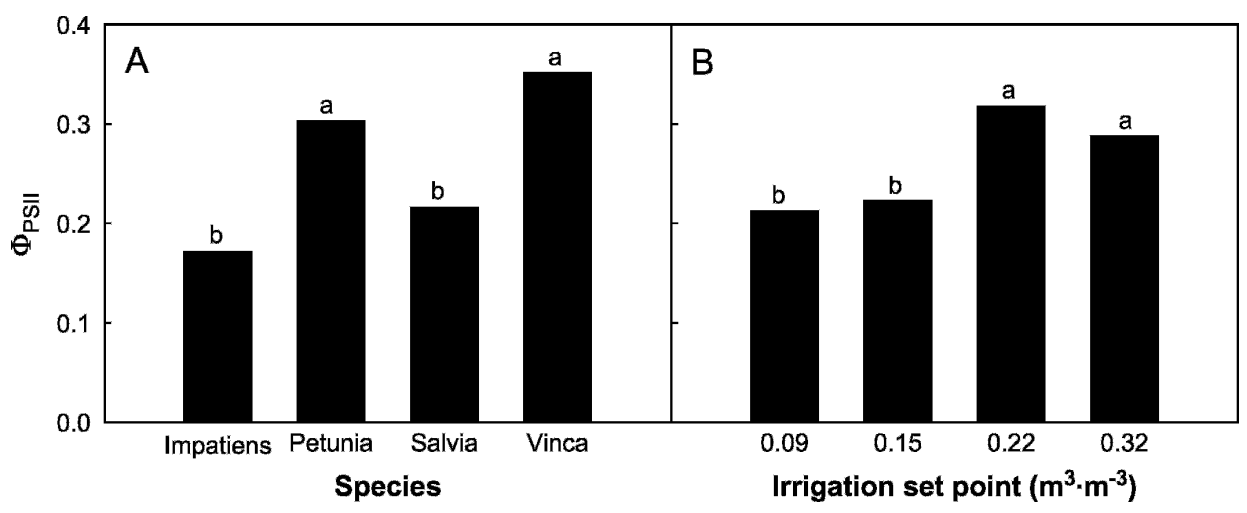

Fig. 5. Time averaged (three times) mean quantum efficiency in light $\left(\Phi_{\mathrm{PSII}}\right)$, a measure of the extent to which absorbed light is used in photochemistry, from chlorophyll-a fluorescence measurements for (A) different bedding plant species ( $\mathrm{n}=2$ for each irrigation set point) and (B) different irrigation set points $(\mathrm{n}=2$ for each species). Quantum efficiency was measured using a hand-held Mini-PAM (Heinz Walz GmbH) at a $P P F$ density of 1000 of $1100 \mu \mathrm{mol} \cdot \mathrm{m}^{-2} \cdot \mathrm{s}^{-1}$. Means were separated by Tukey's HSD $(P<0.05)$.

Table 1. Physiological parameters estimated from leaf photosynthesis-leaf internal $\mathrm{CO}_{2}$ response curve [A-C $\mathrm{C}_{\mathrm{i}}$ analysis (see Fig. 6 and "Materials and Methods" for more details)] in petunia and salvia grown at constant irrigation set points of 0.15 and $0.22 \mathrm{~m}^{3} \cdot \mathrm{m}^{-3}$. Species means were separated using Tukey's HSD $(P=0.05)$.

\begin{tabular}{lcc}
\hline & Petunia & Salvia \\
\cline { 2 - 3 } Physiological parameter & \multicolumn{2}{c}{ (mean $\pm \mathrm{SD})$} \\
\hline $\mathrm{CO}_{2}$ compensation point $\left(\mu \mathrm{mol} \cdot \mathrm{mol}^{-1}\right)$ & $158 \pm 8 \mathrm{~b}$ & $41.0 \pm 5.7 \mathrm{a}$ \\
Operating $\mathrm{C}_{\mathrm{i}}\left(\mu \mathrm{mol} \cdot \mathrm{mol}^{-1}\right)$ & $9.16 \pm 0.64 \mathrm{a}$ & $194 \pm 8 \mathrm{a}$ \\
Operating A $\left(\mu \mathrm{mol} \cdot \mathrm{m}^{-2} \cdot \mathrm{s}^{-1}\right)$ & $46 \pm 9 \mathrm{a}$ & $7.60 \pm 0.65 \mathrm{~b}$ \\
Gas phase conductance to $\mathrm{CO}_{2}\left(\mathrm{mmol} \cdot \mathrm{m}^{-2} \cdot \mathrm{s}^{-1}\right)$ & $68 \pm 10 \mathrm{a}$ & $50 \pm 28 \mathrm{a}$ \\
Mesophyll conductance to $\mathrm{CO}_{2}\left(\mathrm{mmol} \cdot \mathrm{m}^{-2} \cdot \mathrm{s}^{-1}\right)$ & $0.243 \pm 0.016 \mathrm{a}$ & $0.206 \pm 0.016 \mathrm{~b}$
\end{tabular}

Means of physiological parameters followed by a different letter are statistically different.

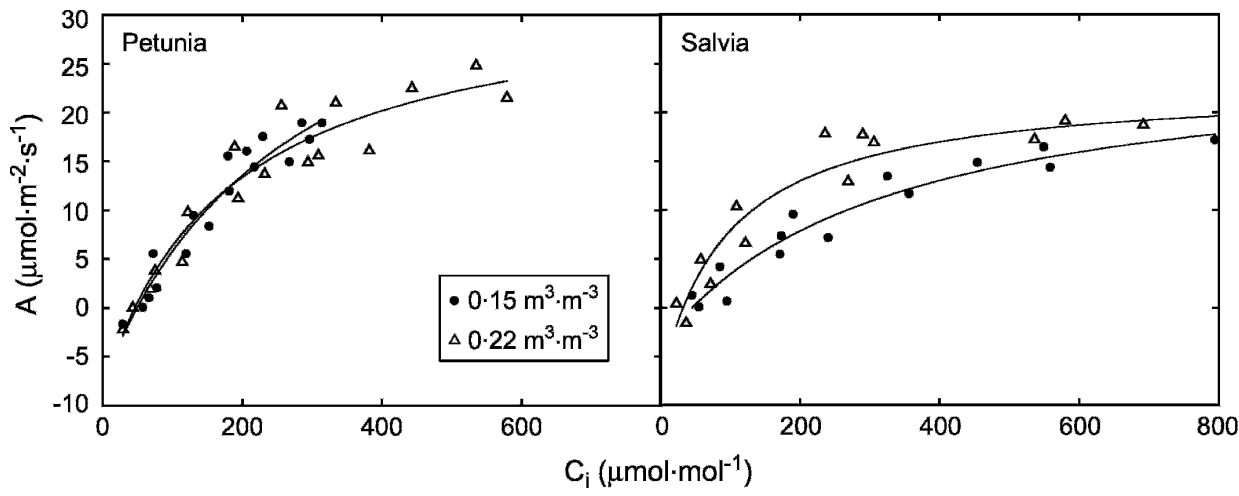

Fig. 6. Relationship between leaf photosynthetic rate (A) and leaf internal $\mathrm{CO}_{2}$ concentration $\left(\mathrm{C}_{\mathrm{i}}\right)$ in petunia and salvia grown at two constant irrigation regimes. The measurements were taken at harvest using a leaf photosynthesis system (CIRAS-1; PP Systems). A rectangular hyperbola was fitted to describe the response in all treatments. The fitted equations for petunia at set points of 0.22 and $0.15 \mathrm{~m}^{3} \cdot \mathrm{m}^{-3}$ were $\mathrm{A}=-8.36+([41.51 \times$ $\left.\left.\mathrm{C}_{\mathrm{i}}\right] /\left[181.65+\mathrm{C}_{\mathrm{i}}\right]\right), R^{2}=0.92$ and $\mathrm{A}=-7.70+\left(\left[50.18 \times \mathrm{C}_{\mathrm{i}}\right] /\left[271.76+\mathrm{C}_{\mathrm{i}}\right]\right), R^{2}=0.92$, respectively. The fitted equations for salvia at 0.22 and $0.15 \mathrm{~m}^{3} \cdot \mathrm{m}^{-3}$ were $\mathrm{A}=-7.24+\left(\left[31.25 \times \mathrm{C}_{\mathrm{i}}\right] /\left[108.71+\mathrm{C}_{\mathrm{i}}\right]\right), R^{2}=0.92$ and $\mathrm{A}=-3.06+\left(\left[28.44 \times \mathrm{C}_{\mathrm{i}}\right] /\left[346.90+\mathrm{C}_{\mathrm{i}}\right]\right), R^{2}=0.86$, respectively.

(e.g., $g_{m}$ ) could be from more severe limitations of RuBP synthesis (or electron transport rate) on photosynthesis in salvia compared with petunia. In support of this, $\Phi_{\text {PSII }}$ (a measure of electron transport rate; Maxwell and Johnson, 2000) at ambient $\mathrm{CO}_{2}$ concentration (Fig. 5A) was lower in salvia compared with petunia. These results suggest that the higher photosynthetic capacity in petunia compared with salvia could be from a higher photochemical efficiency (efficiency with which absorbed 
light is used by photosystem II). Supporting this, it was previously proposed that increased light absorption capacity can increase $g_{m}$ (Earl, 2002) and $g_{m}$ is directly related to chlorophyll a $+\mathrm{b}$ concentration (Singsaas et al., 2003). Thus, it may be possible to use the technique of chlorophyll fluorescence to rapidly screen for photosynthetic capacity and WUE of plants.

\section{Conclusions}

This study shows that the leaf photosynthetic rate of bedding plants is similar at $\theta$ levels of $0.15,0.22$, and $0.32 \mathrm{~m}^{3} \cdot \mathrm{m}^{-3}$, whereas conductance (thereby transpirational water loss) of plants grown at 0.15 and $0.22 \mathrm{~m}^{3} \cdot \mathrm{m}^{-3}$ was lower than those grown at $0.32 \mathrm{~m}^{3} \cdot \mathrm{m}^{-3}$. Therefore, substrate water content for optimum gas exchange of the bedding plants studied is in the range of 0.15 to $0.22 \mathrm{~m}^{3} \cdot \mathrm{m}^{-3}$. Species and substrate water content affected the WUE of plants. In general, optimal WUE was seen at a $\theta$ level of $0.22 \mathrm{~m}^{3} \cdot \mathrm{m}^{-3}$ for the studied species. Differences in WUE between petunia and salvia were associated with inherent differences in $g_{m}$ (or photosynthetic capacity). Therefore, it may be possible to screen for high WUE by screening for a high $\mathrm{g}_{\mathrm{m}}$.

\section{Literature Cited}

Adams W.W., III and B. Demmig-Adams. 1992. Operation of xanthophyll cycle in higher plants in response to diurnal changes in incident sunlight. Planta 186:390-398.

Araus, J.L., G.A. Slafer, M.P. Reynolds, and C. Royo. 2002. Plant breeding and drought in $\mathrm{C}_{3}$ cereals: What should we breed for? Ann. Bot. (Lond.) 89:925-940.

Baille, M., R. Romerio-Aranda, and A. Baille. 1996. Gas-exchange responses of rose plants to $\mathrm{CO}_{2}$ enrichment and light. J. Hort. Sci. 71:945-956.

Bonal, D. and J.M. Guehl. 2001. Contrasting patterns of leaf water potential and gas exchange responses in seedlings of tropical rain forest species. Funct. Ecol. 15:440-496.

Close, D.C., C.L. Beadle, and M.J. Hovenden. 2001. Cold-induced photoinhibition and foliar pigment dynamics of Eucalyptus nitens seedlings during establishment. Aust. J. Plant Physiol. 28:11331141.

Colom, M.R. and C. Vazzana. 2003. Photosynthesis and PSII functionality of drought resistant and drought sensitive weeping lovegrass plants. Environ. Exp. Bot. 49:135-144.

Cornic, G., I. Papageorgiou, and G. Louason. 1987. Effect of a rapid and a slow drought cycle followed by rehydration on stomatal and non-stomatal components of photosynthesis in Phaseolus vulgaris $\mathrm{L}$. J. Plant Physiol. 126:309-318.

De Lucia, E.H., D. Whitehead, and M.J. Clearwater. 2003. The relative limitation of photosynthesis by mesophyll conductance in cooccuring species in a temperate rain forest dominated by the conifer Dacrydium cupressinum. Funct. Plant Biol. 30:1197-1204.

Earl, H.J. 2002. Stomatal and non-stomatal restrictions to carbon assimilation in soybean (Glycine $\max$ ) lines differing in water use efficiency. Environ. Exp. Bot. 48:237-246.

Ekanayake, I.J., S.K. De Datta, and P.L. Steponkus. 1993. Effect of water deficit stress on diffusive resistance, transpiration, and spikelet desiccation of rice (Oryza sativa L.). Ann. Bot. (Lond.) 72:73-80.

Epron, D. 1997. Effects of drought on photosynthesis and on the thermotolerance of photosystem II in seedlings of cedar (Cedrus atlantica and C. libani). J. Expt. Bot. 48:1835-1841.

Epron, D., D. Godard, G. Cornic, and B. Gentry. 1995. Limitation of net $\mathrm{CO}_{2}$ assimilation rate by internal resistances to $\mathrm{CO}_{2}$ transfer in the leaves of two tree species (Fagus sylvatica L. and Castanea sativa Mill.). Plant Cell Environ. 18:43-51.
Evans, J.R. and F. Loreto. 2000. Acquisition and diffusion of $\mathrm{CO}_{2}$ in higher plants, p. 321-351. In: R.C. Leegood, T.D. Sharkey, and S. Von Caemmerrer (eds.). Photosynthesis: Physiology and metabolism. Kluwer Academic Publishers, Dordrecht, The Netherlands.

Evans, J.R. and H. Poorter. 2001. Photosynthesis acclimation of plants to growth irradiance: The relative importance of specific leaf area and nitrogen partitioning in maximizing carbon gain. Plant Cell Environ. 24:755-767.

Flexas, J., J.M. Escalona, and H. Medrano. 1999. Water stress induces different levels of photosynthesis and electron transport rate regulation in grapevines. Plant Cell Environ. 22:39-48.

Funnell, K.A., E.W. Hewett, J.A. Plummer, and I.J. Warrington. 2002. Acclimation of photosynthetic activity of Zantedeschia 'Best Gold' in response to temperature and photosynthetic photon flux. J. Amer. Soc. Hort. Sci. 127:290-296.

Gindaba, J., A. Rozanov, and L. Negash. 2005. Photosynthetic gas exchange, growth and biomass allocation of two Eucalyptus and three indigenous tree species of Ethiopia under moisture deficit. For. Ecol. Mgt. 205:127-138.

Grassi, G. and F. Magnani. 2005. Stomata, mesophyll conductance and biochemical limitations to photosynthesis as affected by drought and leaf ontogeny in ash and oak trees. Plant Cell Environ. 28:834849.

Jones, H.J. 1985. Partitioning stomatal and non-stomatal limitations to photosynthesis. Plant Cell Environ. 8:95-104.

Jones, H.J. 1992. Plants and microclimate: A quantitative approach to environmental plant physiology. 2nd ed. Cambridge Univ. Press, Cambridge, UK.

Jones, H.J. 1998. Stomatal control of photosynthesis and transpiration. J. Expt. Bot. 49:387-398.

Kyei-boahen, S., R. Lada, T. Astatkie, R. Gordon, and C. Caldwell. 2003. Photosynthesis responses of carrots to varying irradiances. Photosynthetica 41:301-305.

Lambers, H., E.S. Chapin, III and T.L. Pons. 1998. Plant physiological ecology. Springer, New York.

Lawlor, D.W. 2002. Limitation to photosynthesis in water stressed leaves: Stomata vs. metabolism and the role of ATP. Ann. Bot. (Lond.) 89:871-885.

Lea-Cox, J.D. and D.S. Ross. 2001. A review of the federal clean water act and the Maryland water quality improvement act: The rationale for developing a water and nutrient planning process for container nursery and greenhouse operations. J. Environ. Hort. 19:226-229.

Leonardos, E.D., M.J. Tsujita, and B. Grodzinski. 1994. Net carbon dioxide exchange rates and predicted growth patterns in Alstroemeria 'Jacqueline' at varying irradiances, carbon dioxide concentrations, and air temperature. J. Amer. Soc. Hort. Sci. 119:1265-1275.

Liu, F., A. Shahnazari, M.N. Andersen, S.E. Jacobson, and C.R. Jense. 2006. Effects of deficit irrigation (DI) and partial root drying (PRD) on gas exchange, biomass partitioning, and water use efficiency in potato. Scientia Hort. 109:113-117.

Long, S.P. and C.J. Bernacchi. 2003. Gas exchange measurements. What can they tell us about the underlying limitations to photosynthesis? Procedures and sources of error. J. Expt. Bot. 54:2393-2401.

Loreto, F., P.C. Harley, G.D. Marco, and T.D. Sharkey. 1992. Estimation of mesophyll conductance to $\mathrm{CO}_{2}$ flux by three different methods. Plant Physiol. 98:1437-1443.

Ludlow, M.M. 1987. Contribution of osmotic adjustment to maintenance of photosynthesis during water stress, p. 161-168. In: J. Biggens (ed.). Progress in photosynthesis research, Vol. 4. Martinus Nijhoff, Dordrecht, The Netherlands.

Marenco, R.A., J.F.C. Gonglaves, and G. Vieira. 2001. Leaf gas exchange and carbohydrates in tropical trees differing in success ional status in two light environments in central Amazonia. Tree Physiol. 21:1311-1318.

Maxwell, K. and N. Johnson. 2000. Chlorophyll fluorescence: A practical guide. J. Expt. Bot. 345:659-688. 
McCree, K.J. 1986. Whole plant carbon balance during osmotic adjustment to drought and salinity stress. Aust. J. Plant Physiol. 13:33-43.

McKay, J.K., J.H. Richards, and T. Mitchell-Olds. 2003. Genetics of drought adaptation in Arabidopsis thaliana. I. Pleiotropy contributes to genetic correlations among ecological traits. Mol. Ecol. 12:11371151.

Nemali, K.S. and M.W. van Iersel. 2004. Light effects on wax begonia: Photosynthesis, growth respiration, maintenance respiration and carbon use efficiency. J. Amer. Soc. Hort. Sci. 129:416-424.

Nemali, K.S. and M.W. van Iersel. 2006. An automated system for controlling drought stress and irrigation in potted plants. Scientia Hort. 110:292-297.

Niu, G., D.S. Rodriguez, and Y.-T. Wang. 2006. Impact of drought and temperature on growth and leaf gas exchange of six bedding plant species under greenhouse conditions. HortScience 41:1408-1411.

Olson, D.L., R.D. Oetting, and M.W. van Iersel. 2002. Effect of potting media and water management on development of fungus gnats (Diptera: Sciaridae) and plant growth. HortScience 37:919-923.

Parry, M.A.J., P.J. Andralojc, S. Khan, P.J. Lea, and A.J. Keys. 2002. Rubisco activity: Effects of drought stress. Ann. Bot. (Lond.) 89:833-839.

Piel, C., E. Frak, X.L. Roux, and B. Gentry. 2002. Effect of local irradiance on $\mathrm{CO}_{2}$ transfer conductance of mesophyll in walnut. J. Expt. Bot. 53:2424-2430.

Plaut, Z., Y. Magril, and U. Kedem. 2004. A new film forming material that reduces water vapor conductance more than $\mathrm{CO}_{2}$ fixation in several horticultural crops. J. Hort. Sci. Biotechnol. 79:528-532.

Ray, J.D. and T.R. Sinclair. 1998. The effect of pot size on growth and transpiration of maize and soybean during water deficit stress. J. Expt. Bot. 49:1381-1386.

Saccardy, K., G. Cornic, J. Brulfert, and A. Reyss. 1996. Effect of drought stress on net $\mathrm{CO}_{2}$ uptake by Zea leaves. Planta 199:589-595.

Sato, F., H. Yoshioka, T. Fujiwara, H. Higashio, and A. Uragami. 2004. Physiological responses of cabbage plug seedlings to water stress during low temperature storage in darkness. Scientia Hort. 101:349-357.

Sheshshayee, M.S., H. Bindumadhava, R. Ramesh, T.G. Prasad, M.R. Lakshminarayana, and M. Udayakumar. 2005. Oxygen isotope enrichment $\left(\Delta^{18} \mathrm{O}\right)$ as a measure of time-averaged transpiration rate. J. Expt. Bot. 56:3033-3039.

Sinclair, T.R. and M.M. Ludlow. 1986. Influence of soil water supply on the plant water balance of four tropical grain legumes. Aust. J. Plant Physiol. 13:329-341.

Singsaas, E.L., D.R. Ort, and E.H. DeLucia. 2003. Elevated $\mathrm{CO}_{2}$ effects on mesophyll conductance and its consequences for interpreting photosynthesis physiology. Plant Cell Environ. 27:41-50.

Starman, T. and L. Lombardini. 2006. Growth, gas exchange, and chlorophyll fluorescence of four herbaceous perennials during water deficit conditions. J. Amer. Soc. Hort. Sci. 131:469-475.

Tezara, W., V.J. Mitchell, S.D. Driscoll, and D.W. Lawlor. 1999. Water stress inhibits plant photosynthesis by decreasing coupling factor and ATP. Nature 401:914-917.

Udayakumar, M., M.S. Sheshshayee, K.S. Natraj, H. Bindumadhava, R. Devendra, I.S. Aftab-Hussain, and T.G. Prasad. 1998. Why breeding for water-use efficiency has not been successful. An analysis and alternate approach to exploit this trait for crop improvement. Curr. Sci. 74:996-1000.

U.S. Department of Agriculture. 2006. Floriculture crops 2005 summary. USDA, National Agricultural Statistics Service, Washington, DC.

Wahbi, S., R. Wakrim, B. Aganchich, H. Tahi, and Serraj. 2005. Effects of partial rootzone drying (PRD) on adult olive tree (Olea europaea) in field conditions under and climate. I. physiological and agronomic responses. Agr. Ecosystems Environ. 106:289-301.

$\mathrm{Xu}, \mathrm{Z} . \mathrm{Z}$. and G.-S. Zhou. 2005. Effects of water stress and high nocturnal temperature on photosynthesis and nitrogen level of a perennial grass Leymus chinenesis. Plant Soil 269:131-139. 